\title{
Ecological Analysis of Health Resource Related to Measles at Primary Health Center in Indonesia
}

\author{
Nurul Jannatul Firdausi ${ }^{1}$, Zainatul Mufarrikoh ${ }^{2}$, Hario Megatsari ${ }^{3}$, Agung Dwi Laksono ${ }^{4}$, Mursyidul Ibad $^{5}$ \\ ${ }^{1}$ Researcher, Health Resource Department, Provincial Health Office of East Java, Surabaya, Indonesia, ${ }^{2}$ Lecturer, \\ National Institute of Islamic Religion, Pamekasan, Indonesia, ${ }^{3}$ Lecturer, Faculty of Public Health, University \\ of Airlangga, Surabaya, Indonesia, ${ }^{4}$ Researcher, National Institute of Health Research and Development, The \\ Indonesia Ministry of Health, Jakarta, Indonesia, ${ }^{5}$ Lecturer, Faculty of Health, NadlatulUlama University,
} Surabaya, Indonesia

\begin{abstract}
Measles is a vaccine-preventable disease. The case increases over the past 3 years in Indonesia. The study aimed to analyze the correlation between health resources and measles. The ecological analysis was conducted using secondary data from the Ministry of Health report in 2019. All provinces were taken as samples. Apart from measles cases as a dependent variable, while the independent variable consists of a ratio of public health center (PHC), a number of active Posyandu(Integrated Health Post), adequacy of midwives, availability of five typesof promotive-preventive health workers at PHC, availability of drug and essential vaccine at PHC and the obedience of district drug warehouse to applied good management of drug and vaccine. The univariate analysis shows a descriptive table. Bivariate analyses were analyzed using a scatter plot. The results showa gap of measles cases between province in Indonesia were uneven. The highest measles cases occurred at Central Java (1.310cases) and the lowest at North Maluku ( 0 cases). The mean of suspect measles was 226 , the higher cases of mean were dominated at Java. The variable of health worker and health logistic depict a random pattern with measles cases. It was concluded that the effectiveness of health workers to prevent measles was measured by their performance. As well as optimizing the potential of five types of promotive-preventive health workers at the PHC. The choice of method in distribution management and vaccine management at the health center level must be a concern.
\end{abstract}

Keywords: ecological analysis, health resources, measles, primary health center.

\section{Background}

Measles is a public health challenge in Indonesia. The agent is Paroxymyvirusthat highly contagious and often cause outbreaks. The disease cause life long complications even mortality. The disease infects the respiratory tract which is transmitted through droplets containing a virus. Symptoms of measles include high fever, skin rash, and cough. Humans asa host who transmitted the disease ${ }^{1}$. People with measles are very susceptible to infected by other diseases caused attacked

\section{Corresponding Author:}

\section{Hario Megatsari}

Email: hario.megatsari@fkm.unair.ac.id the respiratory tract and the immune system ${ }^{2}$.

Half of global measles mortality came from SouthEast Region (SEARO) ${ }^{3}$.Indonesia is one of the "big six countries" with measles endemic ${ }^{4}$.The susceptible group of measles in Indonesia wasa child aged more than 1-year-old, unvaccinated infants, adolescents, and young adultsfor the second dose. The high incidence of measles occurred in a child aged less than 5 years were reached $5 \%$ in $2013^{5}$.More than 11,000 cases of suspected measles are reported in Indonesia each year, as much as $12 \%$ to $39 \%$ were being confirmed measles. The incidence rate of measles per 100,000 population during 2011-2017 tends to decline but tends to increase in the last 3 years (2015-2017). The frequency of measles outbreak has also increased over the last 3 years 
(2015-2017). Measles outbreak report coverage during 2015-2017 spread wider to 30 provinces (before only 27 provinces) ${ }^{6}$.

Measles elimination is targeted to be achieved by 2020, however,measles cases finding an increasein 2019. Ensuring the quality of immunization can be seen from the aspect of facilities and service providers.A studyfound inadequate the facility of the vaccine will encourage the measles risk ${ }^{2}$. According to the background, the study aimed to analyze the correlation between health resources with the case of suspected measles at primary healthcare.

\section{Materials and Methods}

The study was designed using an ecological analysis approach. Ecological studies focus on comparisons between groups, not individuals. The data analyzedwas aggregate data at a certain group or level, which in this study was the province level. The variables in an ecological analysis can be aggregate measurements, environmental measurements, or global measurements ${ }^{7,8}$.

The study was conducted using secondary data from the 2019 Indonesia Health Profilereport. A total of 34 provinces in Indonesia were involved in this analysis. The dependent variable in this study was measles cases. There were 3 independent variables analyzed, namely adequacy of midwives at PHC, the availability of five typesof a promotive-preventive health worker at PHC, the obedience of district drug warehouse to applied good management for drug and vaccine.Data were analyzed by univariate and bivariate. The bivariate analysis was performed using the scatter plot.

\section{Results and Discussion}

Measles elimination is a success indicator of Millennium Development Goals (MDGs) to reduce 2 to 3 global child mortality by $2015^{9}$.WHO-SEAR set regional goals for eliminating measles by $2020^{10}$. Indonesia as part of them has conducted a campaign of MR vaccination as government commitment to measles elimination, control of congenital rubella syndromeat $2020^{11}$. The suspected cases of measles in 2019 increased compared to 2018. The number of cases found in 2019 was 8,819 , while in 2018 it was only 8,429. The distribution of suspected measles cases occurred in almost all provinces in Indonesia. Only 1 province out of 34 provinces in Indonesia had no suspected measles cases, namely North Maluku ${ }^{12}$.

Identified nine provinces with suspected measles cases above the average including Central Java $(1,310)$, Jakarta (1,069), Aceh (944), East Java (658), West Java (621), Yogyakarta (591), South Sumatra (568), South Sulawesi (293), and Lampung (252). The case of suspected measles dominated at Java Island. Java was the highest population density in Indonesia. Someone can be infected by measles while doing activities either at home, school,or public space ${ }^{13}$. Research of Yogyakarta found a higher population density will increase the transmission risk of measles. A high-density population encourages easier transmission between people ${ }^{14}$.

Table 1. Descriptive statistics variables of health resources related to measles in Indonesia, 2019

\begin{tabular}{|c|c|c|c|c|c|}
\hline Variable & $\mathbf{N}$ & Minimum & Maximum & Mean & Std. Deviation \\
\hline Case of suspected measles & 34 & 0.00 & 1.310 & 226.32 & 338.73 \\
\hline The adequacy of midwive at PHC & 34 & $0.00 \%$ & $68.45 \%$ & $10.58 \%$ & 16.89 \\
\hline $\begin{array}{c}\text { The availability of five type promotion- } \\
\text { preventive health worker at kecamatanPHC }\end{array}$ & 34 & $13.62 \%$ & $92.19 \%$ & $45.62 \%$ & 17.63 \\
\hline $\begin{array}{c}\text { The obedience of a district drug warehouse } \\
\text { to apply good management for drug and } \\
\text { vaccine }\end{array}$ & 34 & $50.00 \%$ & $100.00 \%$ & $91.48 \%$ & 12.61 \\
\hline
\end{tabular}

Source: The 2019 Indonesia's Health Profile 


\section{Health Worker}

The health worker factor assessed the adequacy of a midwife at PHC and the availability of fivetypesof promotive and preventive personnel at PHC. The adequacy of midwives describedthe proportion of midwives shortage at PHC. Table 1 figured the proportion of midwives shortage exceeding 50\% at Papua (53.26\%) and Jakarta (68.45\%). Three provinces did not declare a shortage of midwives $(0.00 \%)$ including Lampung, Bali, and Bangka Belitung. The proportion of $\mathrm{PHC}$ who have 5 types of promotive-preventive health workersin Indonesia in 2019 is quite low (less than 50\%) and varies between provinces. The lowest percentage was Jakarta (13.65\%). Figure 1 showed a random tendency of all variables of health workers. The highest case of suspected measles in 2019 was in Central Java, both the variable was good. Meanwhile, Jakarta placed at the second rank showed both the variable were low.

Health workersand healthcare facilities were inseparable. Health workers as the main actor of service. The random pattern of results indicated the performance variability of health workers between provinces. In Indonesia, measles immunization is a responsible program of $\mathrm{PHC}$ but nationally also provided at Posyanduby midwife ${ }^{15}$.Besides, the high ratio of Posyandu did not correlate to high coverage of

measles immunization caused lack of health resources ${ }^{16}$, such as the health worker ${ }^{17}$. The geographic disparity caused the immunization coverage of the "big six countries" especially India, Bangladesh, Indonesia, and Myanmar was not the track. The countries can not achieve the outlined goals to eliminated measles by $2020^{4}$. The disparity between the eastern and western regions of Indonesia has inhibited the acceleration of equitable development ${ }^{18,19}$.Although immunization was provided free charge, but not guarantee the immunization coverage achieved the target, especially for the community who live in hardly achievable areas ${ }^{15}$. Thus, the health workerin areas with physical constraints have to innovative programs to increase coverage.

The sufficient of health worker must be well knowledge through measurable and precise training, both the material and target people should be thought to a minimized knowledge gap and good skills of communication $^{16}$. Several studies found increasing the knowledge of parents, especially mothers, regarding the willingness to immunization ${ }^{15}$. Religion could be a source of public distrust, such as Aceh is the only province that applied shari'ah law, while had the lowest measles vaccination coverage at $54 \%{ }^{20}$. The study found related to our study result that cases finding of suspected measles at Aceh placed at the third-ranked after Jakarta ${ }^{12}$.

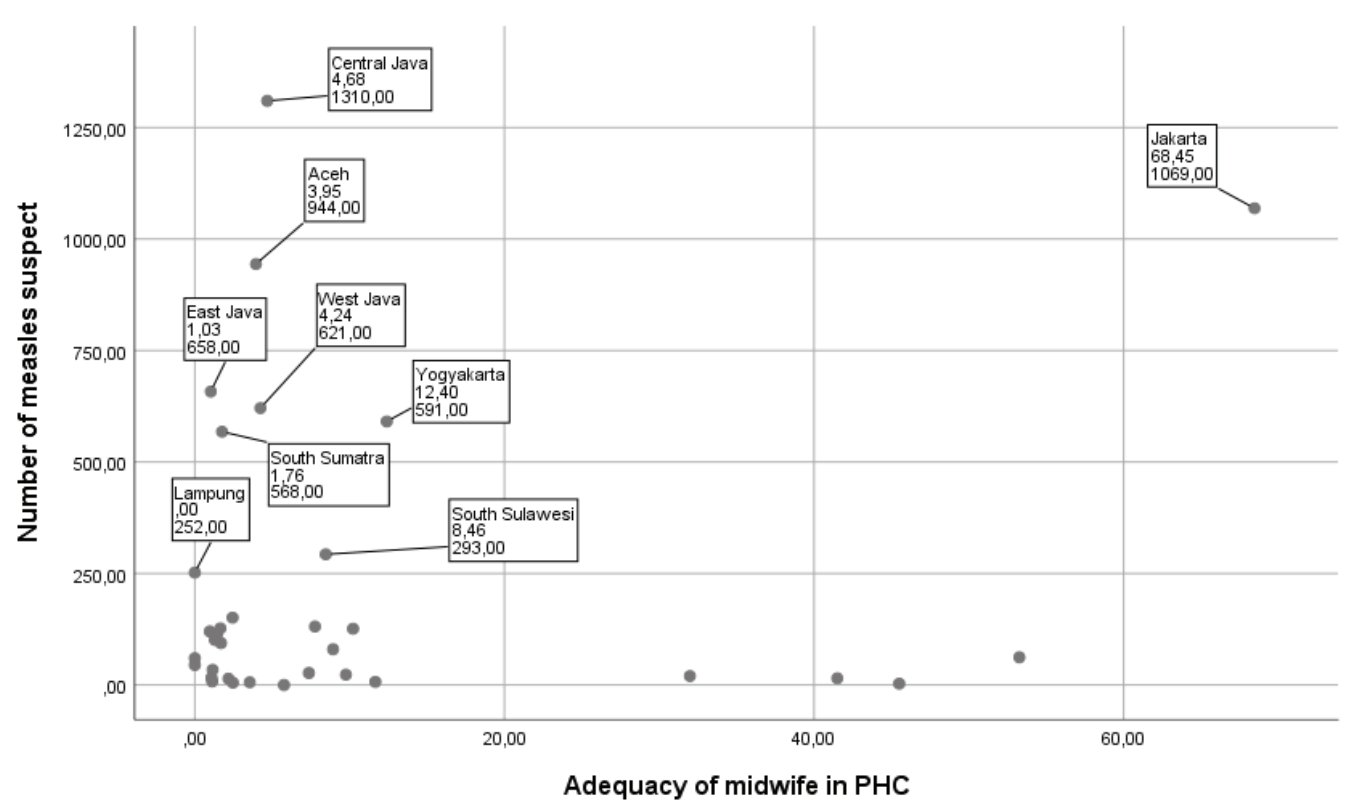




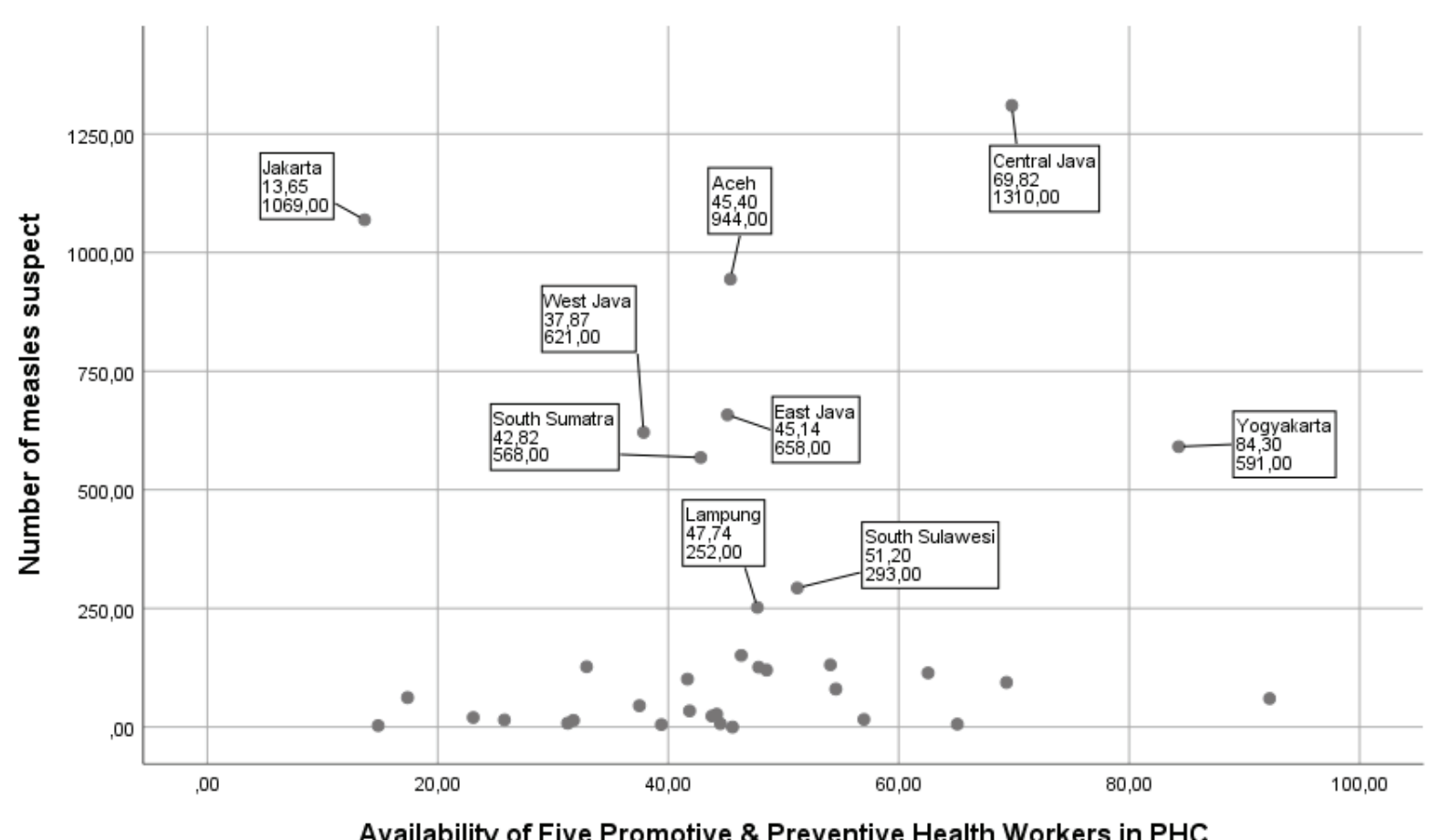

Figure1. Scatter plot of suspected measles cases with the variable of health worker in Indonesia, 2019

Source: TheMinistry of Health of the Republic of Indonesia, 2019

According to the Regulation of Minister of Health number 75, 2014, the PHC is required to recruit at least five types of promotive and preventive health workers, consist ofpharmacy personnel,medical laboratory technologist, nutritionist, public health professional, and sanitarian $^{21}$. The health worker should be strengthened promotive-preventive program at the PHC level, such as surveillance. Evaluation of measles surveillance in East Java was weak. The problems include the accuracy and completeness of data. Besides, it is related to a lack of human resources ${ }^{5}$. A study of North Sumatera also recommended to all $\mathrm{PHC}$ and authorities to conduct a strict measles surveillance ${ }^{13}$. According to the study, in the low-middle, doctors and nurses were prioritized to provide services, including promotive-preventives. Meanwhile, the promotive-preventive health worker has the appropriate competence for strengthening surveillance. Unfortunately, the distribution of them varied focused on near urban, accredited, and independent financial ${ }^{22}$.

\section{Health Logistic}

Health logistic assessed the obedience of the district drug warehouse to applied good management for drug and vaccine. Table 1 above $90 \%$ district drug warehouse applied standard management for drug and vaccine. The low coverage wasJakarta (50\%), West Papua (53.85\%), and North Maluku (70\%). Figure 2showed a random tendency of all variables of health logistics. High suspected measles cases occurred in provinces with good health logistics.

Drug and vaccine management at Jakarta has been directly transferred to the sub-district drug warehouse through Regional Budget and Expenditure Income, while the data reported drug management in District Health Office $(\mathrm{DHO})^{12}$. However, the other province from eastern Indonesia which is very likely to be constrained by geographical aspects and supporting facilities for storing drug and vaccine ${ }^{23}$. As cold chain product, the critical point of a vaccine is temperature control. A study at Western Uganda found the vaccine effectiveness is lower inthe Southeast Asian. The effectiveness is influenced by vaccine factors, such as vaccine quality and the adequacy of the cold chain ${ }^{24}$. The study in remote and border areas of Indonesia 
explained unstable electricity and bad weather such as a village in a hard area of a small isle were being inhibited factors on vaccine storage. The electric generator has provided, unfortunately, the operational was constrained by the fuel prices, distance, as well as the road condition ${ }^{15,25}$. Vaccine damage in the PHCfrequently due to geographic constraints, travel time, lack of temperature monitoring, and inadequate supporting facilities such as cool packs ${ }^{26}$.

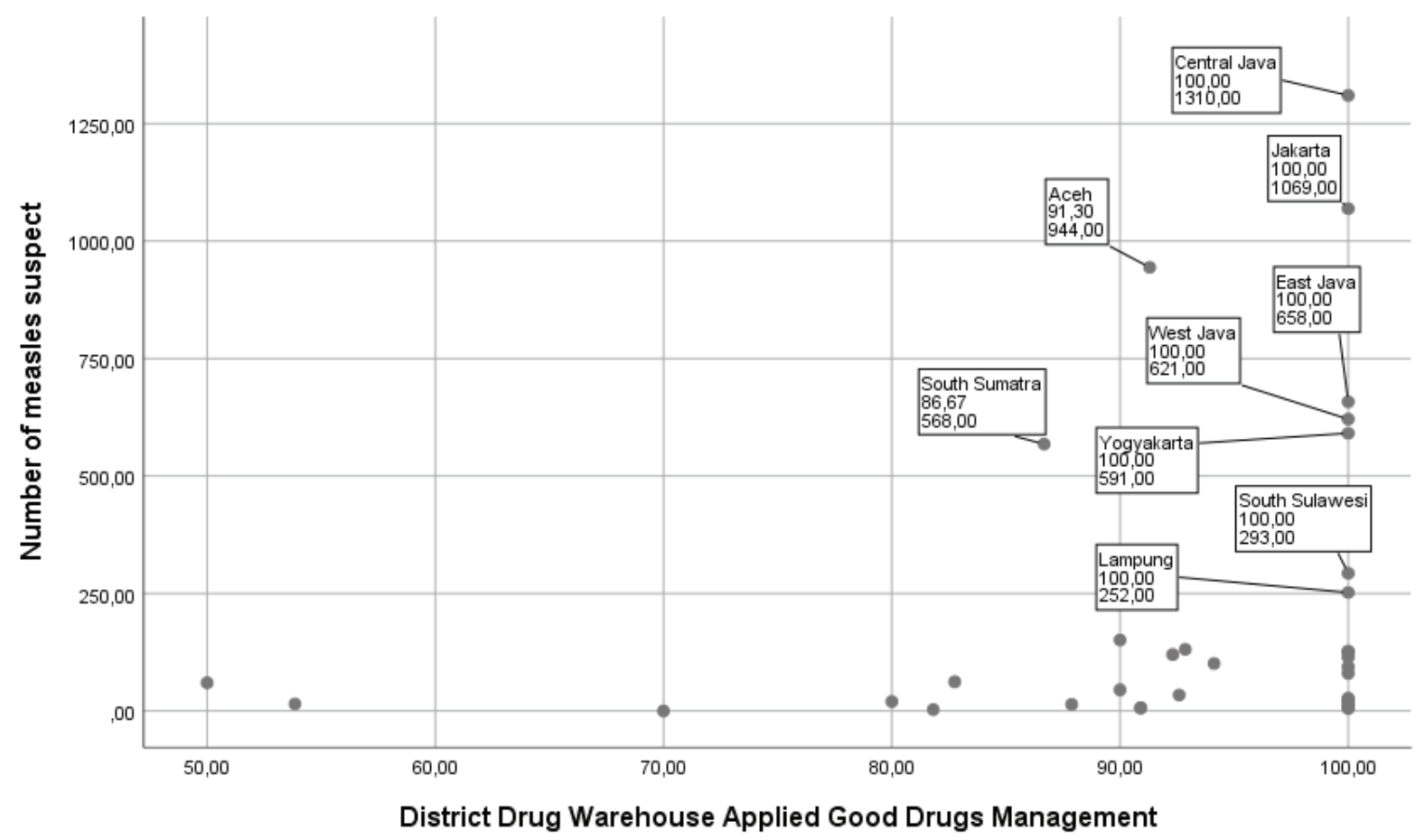

Figure2. Scatter plot of suspected measles cases with the variable of health logistic in Indonesia, 2019

Source: TheMinistry of Health of the Republic of Indonesia, 2019

The assessment provides at the DHO level, while the weakness of drug and vaccine management potentially at PHC and other lower levels. A study at PHC inSidoarjo showed the weakness of recording of a cold chain, consist of weekly and monthly maintenance such as storage tools and routinely temperature recording ${ }^{27}$. Meanwhile, the study at Pasuruan found not standard vaccine distribution facilities, inappropriate treatment vaccine preparation, and vaccine after used by the midwife at Posyand $u^{28}$. Distribution management a crucial process to maintained the vaccine quality. A study figured a better vaccine distribution management in Belitung. The DHO was distributed to PHC. The distribution to the Posyandu by midwifes and supporting by standard facilities such as proper vaccine carrier and an ice pack. As the isle area, the health worker developed a good relationship with the boat's owner, there were almost no problems related to the vaccine's quality in the field ${ }^{15}$.

\section{Conclusions}

All variablesfigures a random tendency, which means no correlation with the number of suspected measles. The effectiveness of health workers to prevent measles was better measured by their performance. As well as optimizing the potential of promotivepreventive health workers at the PHC. Management of vaccine storage and distribution at the PHC level must be a concern. Physical factors, such as geographical and electrical disparity also socio-economics factors, such as religion must be considered as inhibiting factors.

Acknowledgments: Thank you to the Center of Data and Information as part of the Indonesian Ministry of Health for providing the Indonesia's Health Profile in 2019. Through this data, the analysis in this manuscript can be carried out.

Source of Funding: Self-funding 
Ethical Clearance: The study was conducted by utilizing secondary data from published reports. For this reason, ethical clearance is not required in the implementation of this study.

\section{Conflicting Interests: Nil}

\section{References}

1. Suandi D. Optimal Control Problem of Vacination for The Spread of Measles Diseases Model. J Ris dan Apl Mat. 2018;2(2):76.

2. Dilita VGV, Hendrati LY. Measles Distribution Map according to Measles Immunization and Vitamin A Coverage. J Berk Epidemiol. 2019;7(1):17-24.

3. Andriani L. Relationship between Children Under Five Years Characteristics, Age While Measles Immunization, History of Exclusive Breastfeeding with Clinical Measles. J Berk Epidemiol. 2017;5(June):265-72.

4. Gao Y, Kc A, Chen C, Huang Y, Wang Y, Zou S, et al. Inequality in Measles Vaccination Coverage in The "Big Six" Countries of The WHO SouthEast Asia region. Hum Vaccines Immunother. 2020;16(7):1485-97.

5. Kusumawardani EF, Laily SR, Sipahutar RY, Domingga M, Martini S. Evaluation of Measles Surveillance System in Provincial Health Office, East Java, Indonesia. Malaysian J Med Heal Sci. 2020;16(8):43-50.

6. The Ministry of Health. The Situation of Measles and Rubella in Indonesia (Situasi Campak dan Rubella di Indonesia). Data and Information Center of Indonesia. Jakarta; 2018.

7. Laksono AD, Kusrini I. Ecological Analysis of Stunted Toddler in Indonesia. Indian J Forensic Med Toxicol. 2020;14(3):1685-91.

8. Morgenstern H. Ecologic Studies in Epidemiology: Concepts, Principles, and Methods. Annu Rev Public Health. 1995;16:61-81.

9. Perry RT, Gacic-Dobo M, Dabbagh A, Mulders MN, Strebel PM, Okwo-Bele JM, et al. Progress Toward Regional Measles Elimination-Worldwide, 20002016. Morb Mortal Wkly Rep. 2014;63(45):1034108.

10. Afrin S, Mamun KT, Mahboob N, Iqbal H, Jannat
H. Elimination of Measles by 2024: Achievements and Challenges. IMC J Med Sci. 2020;14(1):53-8.

11. Pronyk P, Sugihantono A, Sitohang V, Moran T, Kadandale S, Muller S, et al. Vaccine Hesitancy in Indonesia. Lancet Planet Heal. 2019;3(3):e114-5.

12. The Ministry of Health. The Indonesia's Health Profile 2019 (Profil Kesehatan Indonesia Tahun 2019). Hardhana B, Sibuea F, Widiantini W, editors. Jakarta: Kementerian Kesehatan RI; 2020.

13. Sitepu FY, Depari E, Mudatsir M, Harapan H. Being Unvaccinated and Contact with Measles Cases as The Risk Factors of Measles Outbreak, North Sumatera, Indonesia. Clin Epidemiol Glob Heal. 2019;8(1):239-43.

14. Sulistyawati S, Sumiana S. Measles Cluster Detection Using Ordinal Scan Statistic Model. Mater Socio Medica. 2018;30(4):282.

15. Aryastami NK, Widyasari R. Immunization's Seeking Behavior for Children: Gender and Geographical Perspectives. Prim Heal Care Open Access. 2018;08(02):1-5.

16. Saraswati PH, Gani A. Socio Economic Factors of Child Basic Immunization: Case of West Java Province. J Medicoeticolegal dan Manaj Rumah Sakit. 2020;9(1):1-12.

17. Fernandez RC, Awofeso N, Rammohan A. Determinants of Apparent Rural-Urban Differentials in Measles Vaccination Uptake in Indonesia. Rural Remote Health. 2011;11(3):1-14.

18. Laksono AD, Rukmini R, Wulandari RD. Regional Disparities in Antenatal Care Utilization in Indonesia. PLoS One. 2020;15(2):e0224006.

19. Kusrini I, Laksono AD. Regional Disparities of Stunted Toddler in Indonesia. Indian J Forensic Med Toxicol. 2020;14(3):1685-91.

20. Harapan H, Shields N, Kachoria AG, Shotwell A, Wagner AL. Religion and Measles Vaccination in Indonesia, 1991-2017. Am J Prev Med. 2020;GVAX(000):1-9.

21. Shofiah R, Prihatini D, Viphindartin S. Availability of Promotive and Preventif Health Services for Public Health Center in Jember District. J Multidiscip. 2019;2(1):16-20.

22. Rosita, Su'udi A, Mujiati, Mardikani S, Wibowo. Availability of Health Workers of Promotion and 
Prevention Services at Public Health Center in Indonesia (Analysis of Health Sector Workers Research Data 2017). Adv Heal Sci Res. 2020;22:482-7.

23. Ipa $M$, Widawati $M$, Laksono $A D$, Kusrini I, Dhewantara PW. Variation of Preventive Practices and Its Association with Malaria Infection in Eastern Indonesia: Findings from communitybased survey. PLoS One. 2020;15(5):e0232909.

24. Nsubuga F, Bulage L, Ampeire I, Matovu JKB, Kasasa S, Tanifum P, et al. Factors Contributing to Measles Transmission during An Outbreak in Kamwenge District, Western Uganda, April to August 2015. BMC Infect Dis. 2018;18(1):1-7.

25. Suharmiati, Laksono AD, Astuti WD. Policy Review on Health Services in Primary Health Center in the Border and Remote Area (Review
Kebijakan tentang Pelayanan Kesehatan Puskesmas di Daerah Terpencil Perbatasan). Bull Heal Syst Res. 2013;16(2):109-16.

26. Saraswati LD, Ginandjar P, Budiyono, Martini, Udiyono A, Kairul. Vaccines Cold Chain Monitoring: A Cross Sectional Study at Three District in Indonesia. IOP Conf Ser Earth Environ Sci. 2018;116(1):0-8.

27. Hikamarida F. Relatiopnship Between Storage and Recording with Quality of DPT Vaccine Cold Chain in Puskemas. J Berk Epidemiol Vol 2 N0 3 Sept 2014 380-391. 2014;2(22):283.

28. Ningtyas DW, Wibowo A. The Influence of Quality of Measles Vaccine to The Incidence of Measles in Pasuruan Regency. J Berk Epidemiol. 2017;3(42):315-26. 